\title{
CÓ GÌ KHÁC BIẸTT CỦA BỆNH ĐÁI THÁO ĐƯờNG TYP 2 Ở TRẺ EM VÀ VỊ THÀNH NIÊN SO VỚI NGƯỜI LỚN
}

Hoàng Trung Vinh Học viện Quân y

DOI: 10.47122/vjde.2020.38.1

\section{ABSTRACT \\ Are there different between type 2 diabetes in children-adolescents and adults}

Type 2 diabetes mellitus is a complex, chronic metabolic disease, presents a heterogeneous etiology, with risk factors at the social level and behavioral, environmental, and genetic susceptibility. It is associated with serious complications, but the early diagnosis and initiation of therapy may prevent or delay the onset of long-term complications. In children and adolescents, it was observed in particular increasing the prevalence of T2DM along with obesity, which is associated with insulin resistance. Patient and family education for a young person with T2DM is very important and will focus on behavioral changes (diet and activity).

Keywords: type 2 diabetes mellitus, obesity, insulin resistance, children, adolescent

\section{TÓM TẮT}

Đái tháo đường typ 2 (ĐTĐT2) là bệnh chuyển hóa đa yếu tố mạn tính, xuất hiện với nguyên nhân không đồng nhất cùng với các yếu tố nguy cơ (YTNC) từ phía xã hội và hành vi, môi trường, tính mẫn cảm của gen. Bệnh liên quan đến nhiều biến chứng nguy hiểm song nếu chẩn đoán sớm và bắt đầu điều trị ngay tại thời điểm chẩn đoán có thể dự phòng hoặc làm chậm sự xuất hiện các biến chứng về sau. Ở trẻ em và vị thành niên bệnh ĐTĐT2 đang gia tăng về số lượng liên quan đến béo phì với đặc điểm chủ yếu là kháng insulin. Bản thân người bệnh và sự giáo dục, chăm sóc của gia đình ở đối tượng trẻ tuổi mắc ĐTĐT2 là rất quan trọng chủ yếu khu trú vào việc thay đổi hành vi (ăn uống và hoạt động thể lực).

Tù khóa: đái tháo đương typ 2, béo phì, kháng insulin, trẻ em, vị thành niên.
Chịu trách nhiệm chính: Hoàng Trung Vinh

Ngày nhận bài:10/1/2020

Ngày duyệt bài: 28/02/2020

Email:hoangvinh.hvqy@gmail.com

ĐT: 0903201250

\section{1. ĐẠTT VẤN ĐỀ}

Cùng với sự gia tăng tỷ lệ béo phì ở trẻ em và vị thành niên trên toàn thế giới kéo theo nguy cơ gia tăng các bệnh bao gồm tim mạch, ĐTĐT2, hội chứng chuyển hóa, bệnh gan nhiễm mỡ không do rượu, viêm xương khớp, ngưng thở lúc ngủ, một số bệnh ung thư. Đái tháo đường là bệnh chuyển hóa đa yếu tố mạn tính, xuất hiện với nguyên nhân không đồng nhất cùng các yếu tố nguy cơ từ phía xã hội và hành vi, môi trường và tính mẫn cảm của gen. Bệnh liên quan đến nhiều biến chứng nguy hiểm song nếu chẩn đoán sớm và bắt đầu điều trị ngay tại thời điểm chẩn đoán có thể dự phòng được hoặc làm chậm sự tiến triển các biến chứng về lâu dài. Các biến chứng mạn tính của ĐTĐ bao gồm bệnh tim mạch, bệnh thận mạn giai đoạn cuối, bệnh võ̃ng mạc dẫn đến mù lòa, cắt cụt chi. Tất cả các biến chứng dẫn đến gia tăng bệnh xuất và tử xuất ở bệnh nhân ĐTĐT2. Các biện pháp điều trị mới giúp trẻ em ĐTĐT2 sống dài hơn và có chất lượng cuộc sống tốt hơn.

\section{2. ĐẶC ĐIỂM ĐỊA LÝ VÀ DỊCH TẼ HỌC}

Đái tháo đường typ 2 ở trẻ em và vị thành niên xuất hiện liên quan đến sắc tộc và nòi giống, trong đó hay gặp nhất là người $M y ̃$ bản địa, người Mỹ gốc Phi, Mỹ La tinh, người Mỹ gốc Châu Á, các bán đảo thuộc Thái Bình Dương. Tỷ lệ ĐTĐT2 ở trẻ em và vị thành niên gia tăng trên toàn thế giới song song với sự gia tăng đối tượng béo phì. Tại Úc, tỷ lệ xuất hiện ĐTĐT2 ở người < 17 tuổi 
là 2/100.000/năm tăng trung bình $27 \%$ từ năm 1990 đến năm 2002. Đái tháo đường typ 1 hay xuất hiện ở trẻ em tuy vậy ĐTĐT2 cũng xuất hiện cứ 1 trong $3 \mathrm{BN}$ trẻ em mới được chẩn đoán ĐTĐ, hiện nay vào khoảng 20-33\%. Tỷ lệ ĐTĐT2 ở trẻ em béo phì còn cao hơn nhiều. Yếu tố nguy cơ cao được kể đến là sắc tộc (người Mỹ gốc Phi, người Tây Ban Nha và Bồ Đào Nha, người Mỹ bản địa), các bán đảo và quần đảo thuộc Thái Bình Dương, người Mỹ gốc Châu Á. Tỷ lệ ĐTĐT2 ở trẻ em và vị thành niên tại Mỹ là 12/100.000 dân trong khi tại các nước Châu Âu thì tỷ lệ này chỉ là 2,5/100.000 dân. Người Mỹ gốc Ấn Độ lại lên đến 22,3/1000 dân lứa tuối 10-14. Trong số vị thành niên béo phì lứa tuổi $>12$ thì tỷ lệ ĐTĐT2 là 0,4 $1 \%$. Tỷ xuất chung ĐTĐT2 ở nhi khoa thấp hơn so với ĐTĐT1.

Mặc dù vậy một số tác giả đã tuyên bố xuất hiện đại dịch ĐTĐT2 ở trẻ em, trở thành một mối quan tâm nghiêm túc trong lâm sàng. Dựa vào các nghiên cứu trong cộng đồng nhận thấy hiện nay có khoảng $8-45 \%$ các ca ĐTĐT2 mới chẩn đoán là thuộc lứa tuổi trẻ em và vị thành niên. Trong một nghiên cứu ĐTĐT2 ở lứa tuổi trẻ tại Mỹ cho thấy tần suất bệnh trong số người Mỹ gốc Ấn Độ lứa tuồi $15-19$ chiếm tỷ lệ rất cao $(49,4 \mathrm{ca} / 100.000$ dân) đứng hành thứ 2 và 3 thuộc về người Mỹ gốc Châu Á, cùng lứa tuổi 15-19 là 22,7 $\mathrm{ca} / 100.000$ dân và các quần đảo thuộc Thái Bình Dương là 19,4 ca /100.000 dân. Hiện nay tỷ lệ ĐTĐT2 ở trẻ em và vị thành niên cũng đang gia tăng ở Nhật Bản, Trung Quốc, Đài Loan, Bangladesh, Australia. Tại Rumania năm 2014 ghi nhận 376 ca mắc ĐTĐ trên toàn quốc ở trẻ em trong đó 16 trường hợp là ĐTĐT2. Hiện nay tại quốc gia này có 2670 trường hợp trẻ em mắc ĐTĐ.

\section{NGUYÊN NHÂN VÀ YẾU TỐ NGUY CO'}

Cũng tương tự như ĐTĐT2 ở người lớn thì ĐTĐT2 ở trẻ em và vị thành niên cũng không xác định được nguyên nhân. Tuy vậy tiền sử gia đình và yếu tố gen đóng vai trò rất quan trọng. Ít hoạt động thể lực và béo phì đặc biệt béo bụng được coi là yếu tố nguy cơ quan trọng. Yếu tố nguy cơ của ĐTĐT2 ở trẻ em và vị thành niên bao gồm:

+ Cân nặng: dư cân là YTNC hàng đầu của ĐTĐT2. Khi béo thì lớp mỡ dư thừa đặc biệt ở dưới da vùng bụng sẽ gây kháng insulin. Mối liên quan giữa béo phì và ĐTĐT2 ở trẻ em thể hiện rõ rệt hơn so với ở người lớn.

+ Không hoặc ít hoạt động thể lực. Nếu hoạt động thể lực thì trẻ em sẽ dễ kiểm soát được cân nặng, sử dụng glucose cho ra năng lượng và sẽ đáp ứng tốt hơn với insulin.

+ Tiền sử gia đình: nguy cơ gia tăng ĐTĐT2 ở trẻ em sẽ gia tăng nếu bố mẹ hoặc anh chị em ruột đã mắc bệnh.

+ Chủng tộc: mặc dù cũng chưa được biết rõ vì sao song các chủng tộc hay xuất hiện ĐTĐT2 ở trẻ em bao gồm người Mỹ gốc Phi, người Bồ Đào Nha, người Mỹ bản địa, người Mỹ gốc Châu Á và quần đảo Thái Bình Dương.

+ Tuổi và giới: đa số ĐTĐT2 xuất hiện bắt đầu ở tuổi dậy thì. Trẻ em gái ở tuổi vị thành niên hay bị hơn so với trẻ em trai.

+ Trọng lượng khi sinh và ĐTĐ thai kỳ: Trọng lượng trẻ khi sinh thấp hoặc người mẹ ĐTĐ thai kỳ là YTNC cao gây ĐTĐT2 ở trẻ em.

Sàng lọc ĐTÐT2 ở trẻ em và vị thành niên.

Khi dư cân (BMI >90\%) cộng với một trong các yếu tố nguy cơ sau:

-Tiền sử gia đình có ĐTĐT2 thuộc thế hệ thứ nhất và thứ 2 .

- Chủng tộc/nòi giống (Châu Á, người Mỹ gốc Ấn Độ, người Mỹ gốc Phi, người Bồ Đào Nha).

- Có dấu hiệu kháng insulin hoặc liên quan đến kháng insulin như hạt $\mathrm{u}$ vàng, tăng huyết áp, rối loạn lipid, hội chứng buồng trứng đa nang.

$$
\text { - Quá béo phì (BMI >99,5\%). }
$$

\section{CO' CHẾ BÊNH SINH}

Cơ chế bệnh sinh ĐTĐT2 ở trẻ em và vị thành niên có nhiều điểm tương đồng so với người lớn trong đó chủ yếu là kháng insulin. Tuổi dậy thì sẽ gia tăng biểu hiện kháng đối với tác dụng của insulin, hậu quả làm tăng 
nồng độ insulin. Sau tuổi dậy thì, đáp ứng nền và kích thích của insulin đã bị suy giảm trung bình khoảng $30 \%$ so với lứa tuồi trước đó. Tăng hormon tăng trưởng tuổi dậy thì có thể là đáp ứng tranh chấp với kháng insulin. Chính vì vậy không ngạc nhiên là ĐTĐT2 xuất hiện ở trẻ em chiếm đa số thuộc lứa tuổi giữa của tuổi dậy thì. Nếu chỉ có kháng insulin đơn thuần sẽ không đủ để gây bệnh ĐTĐ mà cần phải có biểu hiện tiết insulin không tương thích. Chính vì vậy mà ở $\mathrm{BN}$ ĐTĐT2 biểu hiện đồng thời suy giảm cả đáp ứng và tiết insulin, hậu quả dẫn đến tăng glucose máu. Béo phì gây tác dụng ngược lại đối với chuyển hóa glucose là bằng chứng xuất hiện sớm ở trẻ em. Trẻ em béo phì gây tăng insulin song lại giảm khoảng 40\% tác dụng chuyển hóa glucose so với trẻ em không béo phì. Có mối tương quan nghịch giữa độ nhạy insulin và tăng lớp mỡ dưới da bụng rõ hơn so với lớp mỡ ở các vị trí khác.

Chính các tế bào mỡ khi béo phì sẽ tổng hợp và tiết ra các adipokin như leptin, adiponectin và $T N F-\alpha$. Đây lại là các yếu tố gây biến đổi khả năng tiết và độ nhạy insulin, thậm chí là nguyên nhân góp phần gây kháng insulin. Có sự khác nhau về độ nhạy insulin liên quan đến chủng tộc. Trẻ em Mỹ gốc Phi tuổi 7-11 có nồng độ insulin cao hơn so với trẻ em da trắng cùng lứa tuổi.

Gen chính là yếu tố liên quan đến biến đổi chức năng tế bào bêta tụy, có khoảng 850 gen liên quan trong đó số gen biến đổi khoảng 5$59 \%$. Các gen liên quan đến ĐTĐT2 rõ nét nhất bao gồm PPARG, KCNJ11, TCF7LII. Ngoài yếu tố gen thì việc xuất hiện ĐTĐT2 ở trẻ em còn liên quan đến tiền sử gia đình trong đó có trẻ sinh ra nhẹ cân $(<2500$ gram) hoặc ngược lại quá nặng cân (>4000gram), trẻ em gái xuất hiện lông mu trước 8 tuổi. Khi tăng glucose máu sẽ dẫn đến rối loạn áp lực thẩm thấu (tiểu nhiều), tăng khát nước. Đây chính là nguyên nhân dẫn đến mất nước mức độ nặng. Tăng glucose máu kéo dài có thể dẫn đến 2 trạng thái khác biệt nhau của ĐTĐT2 ở trẻ em.

Nhiễm ceton là một biểu hiện rất hay gặp ở trẻ em mắc ĐTĐT2 so với người lớn. Nhiễm ceton, rối loạn điện giải có thể dẫn đến hôn mê hoặc tử vong. Tăng áp lực thẩm thấu xuất hiện khi glucose máu tăng cao (>600mg/dl), mất nước mức độ nặng. Tăng glucose máu mức độ nặng sẽ dẫn đến tăng áp lực thẩm thấu và giảm lưu lượng tuần hoàn trong lòng mạch.

\section{CHẨN ĐOÁN ĐÁI THÁO ĐƯỜNG TYP 2 Ở TRẺ EM}

Hội Đái tháo đường Nhi khoa và vị thành niên quốc tế và Hội ĐTĐ Hoa Kỳ đã đưa ra tiêu chuẩn chẩn đoán ĐTĐT2 ở trẻ em và vị thành niên năm 2015 bao gồm:

+ Glucose máu lúc đói $\geq 7 \mathrm{mmol} / 1$.

+ Glucsoe máu huyết tương $\geq 11,1 \mathrm{mmol} / 1$ sau khi làm nghiệm pháp dung nạp glucose với liều lượng $1,75 \mathrm{gram} / \mathrm{kg}$ (tối đa $75 \mathrm{gram}$ ) đường anhydrous pha với nước.

+ Có triệu chứng của bệnh đái tháo đường như tiểu nhiều, uống nhiều, tiểu đêm sút cân không mong muốn và glucose máu bất kỳ $\geq$ $11,1 \mathrm{mmol} / 1$.

$+\mathrm{HbAlc} \geq 6,5$.

Bảng 5.1. Chẩn đoán phân biệt ĐTĐT2 ở người lớn và trẻ em

\begin{tabular}{|l|l|l|}
\hline \multicolumn{1}{|c|}{ Chỉ số } & \multicolumn{1}{|c|}{ Người lớn } & \multicolumn{1}{c|}{ Trẻ em } \\
\hline \multicolumn{1}{|c|}{ Tuổi } & \multicolumn{1}{|c|}{$>10$} \\
\hline Xuất hiện & Thầm lặng & $\begin{array}{l}\text { Thầm lặng hoặc dấu hiệu tăng } \\
\text { glucose máu }\end{array}$ \\
\hline Giới & Cả hai giới & Chủ yếu nữ \\
\hline $\begin{array}{l}\text { Giảm chức năng tế bào } \\
\text { bêta tụy }\end{array}$ & Thầm lặng (từ từ) & Suy giảm nhanh (dưới 4 năm) \\
\hline Điều trị & $\begin{array}{l}\text { Thay đối lối sống, thuốc } \\
\text { uông các nhóm hoặc insulin }\end{array}$ & $\begin{array}{l}\text { Thay đổi lối sống, metformin } \\
+/- \text { insulin }\end{array}$ \\
\hline Biến chứng, bệnh kết hợp & Muộn & Sớm (sau 2-2,5 năm xuất hiện) \\
\hline
\end{tabular}


Bảng 5.2. Chẩn đoán phân biệt ĐTĐT1, ĐTĐT2 và MODY ở trẻ em và vị thành niên

\begin{tabular}{|c|c|c|c|}
\hline Biểu hiện & ĐTÐT1 & ĐTФT2 & MODY \\
\hline Tuổi & $\begin{array}{l}\text { Bất kỳ tuổi nào, } \\
\text { thường trẻ trước khi } \\
\text { đi học }\end{array}$ & $\begin{array}{l}\text { Đa số trong và sau tuổi } \\
\text { dậy thì (>10 tuổi) }\end{array}$ & $\begin{array}{l}\text { MODY 2: trẻ } \\
\text { MODY 3: vị thành } \\
\text { niên }\end{array}$ \\
\hline Giới & Cả 2 giới nhau nhau & Chủ yếu nữ & Cả hai giới như nhau \\
\hline Béo & Ít gặp & Hay gặp & Ít gặp \\
\hline Liên quan & $\begin{array}{l}5 \% \text { liên quan với } \\
\text { ĐTĐT1 }\end{array}$ & $\begin{array}{l}75-100 \% \text { liên quan } \\
\text { đến ĐTĐT2 }\end{array}$ & $\begin{array}{l}100 \% \text { liên quan đến } \\
\text { MODY }\end{array}$ \\
\hline Chủng tộc & Chủ yếu da trắng & $\begin{array}{l}\text { Chủ yếu người Mỹ } \\
\text { gốc Phi, Bồ Đào Nha, } \\
\text { Châu Á, người Mỹ } \\
\text { gốc Ân độ }\end{array}$ & \\
\hline $\begin{array}{l}\text { Kháng thể kháng tế } \\
\text { bào bêta }\end{array}$ & $85-99 \%$ & Ít gặp & Ít gặp \\
\hline $\begin{array}{l}\text { Nồng độ insulin, } \\
\text { Cpeptid }\end{array}$ & Thấp & $\mathrm{Cao}$ & Thấp \\
\hline Nhiễm ceton & Hay gặp & $<33 \%$ & Ít gặp \\
\hline Bệnh liên quan & $\begin{array}{l}\text { Bệnh tự miễn (tuyến } \\
\text { giáp, thượng thận, } \\
\text { bạch biến) }\end{array}$ & U vàng & $\begin{array}{l}\text { MODY 5: khuyết tật } \\
\text { thận - sinh dục } \\
\text { MODY 8: suy giảm } \\
\text { chức năng ngoại tiết } \\
\text { của tụy }\end{array}$ \\
\hline
\end{tabular}

Bảng 5.3. So sánh đái tháo đường typ 2 ở trẻ em và vị thành niên giữa người da trắng và không da trắng

\begin{tabular}{|l|l|l|}
\hline \multicolumn{1}{|c|}{ Biểu hiện } & \multicolumn{1}{|c|}{ Da trắng } & \multicolumn{1}{c|}{ Không da trắng } \\
\hline $\begin{array}{l}\text { Tuối trung bình khi xuất } \\
\text { hiện bệnh }\end{array}$ & 14 & 12 \\
\hline Giới & Nữ > nam & Nữ > nam \\
\hline Biểu hiện lâm sàng & $\begin{array}{l}50 \% \text { không triệu chứng; } \\
4 \% \text { nhiễm ceton }\end{array}$ & $\begin{array}{l}33 \% \text { không triệu chứng; } \\
5-25 \% \text { nhiễm ceton }\end{array}$ \\
\hline Béo & $90 \%$ & $90 \%$ \\
\hline U vàng & $50 \%$ & $90 \%$ \\
\hline $\begin{array}{l}\text { Liên quan thế hệ 1,2 với } \\
\text { ĐTĐT2 }\end{array}$ & $83 \%$ & $74-100 \%$ \\
\hline
\end{tabular}

* Sàng lọc các bệnh kết hợp ở BN ĐTĐT2 và béo phì ở trẻ em và vị thành niên

+ ĐTĐТ2

- Microalbumin niệu để đánh giá bệnh thận do ĐTĐ.

- Bilan lipid

- Huyết áp

- Khám và chụp đáy mắt.

+ Béo phì

- Các test chẩn đoán bệnh gan nhiễm mỡ không do rượu

- Sàng lọc biểu hiện dấu hiệu ngưng thở khi ngủ do tắc nghẽn

- Trầm cảm

- Hội chứng buồng trứng đa nang ở trẻ em gái tuổi vị thành niên. 


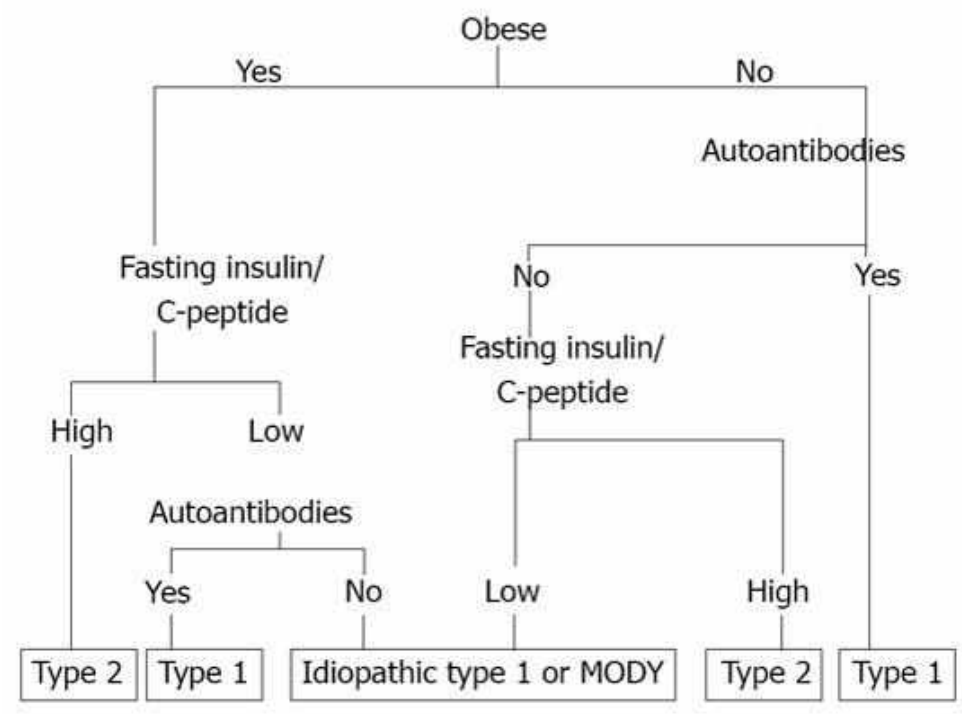

So đồ 5.1. Phân loại typ ĐTĐ ở trẻ em và vị thành niên

* Biến chứng cơ quan đích ĐTĐT2 ở trẻ em và vị thành niên

+ Tăng huyết áp

+ Tăng cholesterol

+ Bệnh tim và mạch máu

+ Đột quỵ não

+ Bệnh gan nhiễm mõ̃ không do rượu

+ Bệnh thận mạn tính

+ Bệnh võng mạc

+ Cắt cụt chi

+ Bệnh da.

\section{6. ĐIỀU TR!}

* Mục tiêu điều trị

+ Giảm cân

+ Tăng cường luyện tập thể lực

+ Đưa glucose máu về bình thường: mục tiêu của $\mathrm{ADA}$ và Học viện nhi khoa Hoa Kỳ: $\mathrm{HbA} 1 \mathrm{c}<7,0 \%$. Hội các nhà nội tiết lâm sàng Hoa Kỳ $\mathrm{HbA} 1 \mathrm{c}<6,5 \%$; glucose < 7,8mmol/1 liên tục 3-4 tháng.

+ Kiểm soát bệnh kèm theo gồm tăng huyết áp, rối loạn lipid máu, bệnh thận mạn và gan nhiễm mỡ.

\subsection{Thay đổi lối sống}

Thay đổi lối sống bằng tiết chế ăn uống và luyện tập thể lực là biện pháp rất quan trọng, dưới $10 \%$ trường hợp đạt được mức kiểm soát glucose máu mục tiêu chỉ bằng thay đổi lối sống. Chế độ ăn giảm đường và các loại thức ăn, đồ uống ngọt, hạn chế năng lượng đưa vào cơ thể. Một nghiên cứu 24 tháng ở 699 ĐTĐT2 ở trẻ em chỉ với thay đổi lối sống bao gồm luyện tập thể lực 200-300 phút /tuần với các hình thức từ trung bình đến nặng, năng lượng đưa vào cơ thể 1200-1500 caloria có thể ngừng sử dụng thuốc đơn trị liệu bằng metformin, hạn chế được các nguy cơ tim mạch như rối loạn lipid, giảm dấu ấn viêm. Luyện tập thể lực mỗi ngày không dưới 60 phút với mức độ trung bình trở lên, giảm thời gian tĩnh tại xuống $<2$ giờ trên ngày.

\subsection{Thuốc điều trị}

Nhìn chung metformin hoặc insulin có thể được lựa chọn khi bắt đầu điều trị, tuy vậy metformin được sử dụng rộng rãi hơn. Metformin được bắt đầu $500 \mathrm{mg} /$ ngày và tăng dần liều mỗi $500 \mathrm{mg}$ trong $1-2$ tuần. Liều lượng tối đa $2000 \mathrm{mg} /$ ngày, chia 2 lần. Không sử dụng metformin khi có bệnh giảm oxi 
không rõ nguyên nhân, nhiễm khuẩn nặng, bệnh gan, làm dụng rượu. Chống chỉ định khi có suy thận hoặc cần tạm dừng ít nhất trước 48 giờ trước khi sử dụng thuốc cản quang để thăm dò chức năng thận và chỉ sử dụng trở lại khi chức năng thận bình thường. Nếu đơn trị liệu bằng metformin trong vòng 3-6 tháng mà không đạt mục tiêu điều trị thì cần phải cân nhắc để thay đổi. Tuy vậy những loại thuốc uống khác chống đái tháo đường rất ít khi sử dụng. TZD không được chỉ định ở ĐTĐT2 trẻ em. Có thể sử dụng các loại thuốc uống khác tương tự như ĐTĐT2 ở người lớn như đồng vận GLP1, ức chế DPP4, SGLT2.

Insulin được chỉ định khi bệnh nhân có ceton niệu hoặc nhiễm toan ceton, khi glucose máu $>250 \mathrm{mg} / \mathrm{dl}, \mathrm{HbAlc}>9 \%$ hoặc khi chẩn đoán chưa rõ là typ 2 của ĐTĐ. Liều lượng insulin cao có thể lên đến $2-3$ đơn vị $/ \mathrm{kg} /$ ngày. Khi sử dụng insulin cần lưu ý tác dụng gây cơ hạ đường huyết, cần theo dõi nồng độ glucose máu tại nhà.

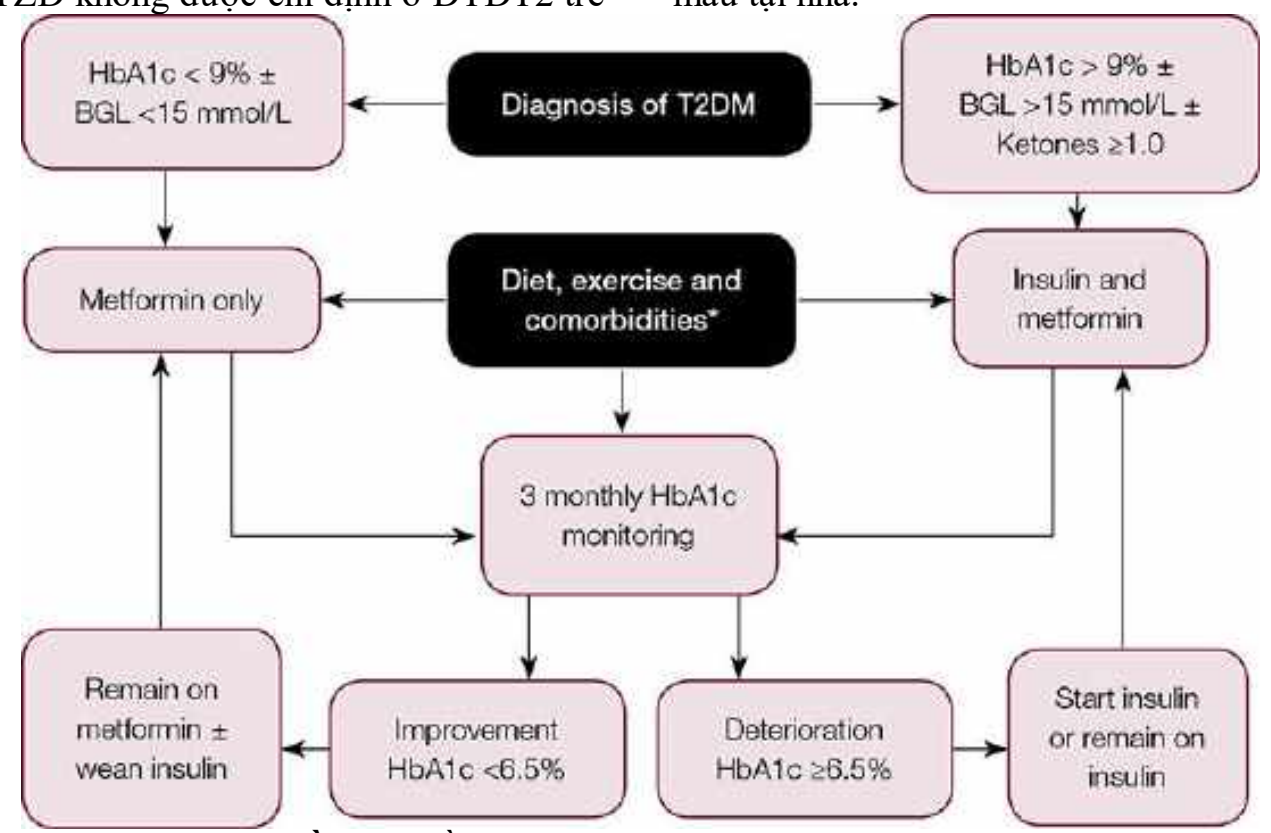

Sơ đồ 6.1. Điều trị ĐTĐT2 ở trẻ em và vị thành niên

Bảng 6.1. Khuyến cáo điều trị biến chứng ĐTĐT2 ở trẻ em và vị thành niên

\begin{tabular}{|c|c|c|c|}
\hline $\begin{array}{c}\text { Bệnh kèm } \\
\text { theo }\end{array}$ & Tỷ lệ & Sàng lọc & Điều trị \\
\hline Tăng huyết áp & $\begin{array}{l}\text { Ảnh hưởng đến } \\
36 \% \text { người trẻ mắc } \\
\text { ĐTĐT2 trong } 1,3 \\
\text { năm. Tỷ lệ lên đến } \\
65 \% \text { khi khảo sát } \\
\text { cắt ngang. }\end{array}$ & $\begin{array}{l}\text { Tại thời điểm chẩn } \\
\text { đoán và mối lần tái } \\
\text { khám }\end{array}$ & $\begin{array}{l}\text { Thay đổi hành vi, giảm cân } \\
\text { nặng, muối ăn, luyện tập } \\
\text { thế lực. Nếu thay đồi lối } \\
\text { sống không kiểm soát được } \\
\text { thì sử dụng ức chế men } \\
\text { chuyển. Thuốc ức chế AT1 } \\
\text { không được chỉ định. }\end{array}$ \\
\hline Rối loạn lipid & $\begin{array}{l}\text { Tăng triglycerid gặp } \\
60-65 \% \text { ở ĐTĐT2 } \\
\text { trẻ em, giảm HDL-c } \\
\text { ở } 73 \%\end{array}$ & $\begin{array}{l}\text { Tại thời điểm chẩn } \\
\text { đoán. Nếu bình thường } \\
\text { thì theo dõi mỗi } 2 \text { năm } \\
\text { một lần sau đó }\end{array}$ & $\begin{array}{l}\text { - Tiết chế ăn uống. } \\
\text { - Nếu sau } 6 \text { tháng không } \\
\text { kiểm soát được thì dùng } \\
\text { statin khi } \\
>3,4 \text { mmol/l. } \\
\text { Fenofibrat nếu triglycerid }\end{array}$ \\
\hline
\end{tabular}




\begin{tabular}{|c|c|c|c|}
\hline & & & $\begin{array}{l}9,3-13 \mathrm{mmol} / 1 \text { và nếu }>10 \\
\text { tuồi vì nguy cơ viêm tụy cấp }\end{array}$ \\
\hline $\begin{array}{l}\text { Bệnh võng } \\
\text { mạc }\end{array}$ & $\begin{array}{l}\text { 9,3\% tại thời điểm } \\
\text { chẩn đoán. } 12,7 \% \\
\text { bệnh võng mạc tăng } \\
\text { sinh khi đạt tuối } 35 . \\
\text { 23,7\% mất thị lực } \\
\text { trung bình ở tuổi } 32\end{array}$ & $\begin{array}{l}\text { Tại thời điểm chẩn } \\
\text { đoán. Nếu bình thường } \\
\text { thì khám thường xuyên. } \\
\text { Nếu bất thường thì } \\
\text { khám nhiều hơn. }\end{array}$ & $\begin{array}{l}\text { Theo chỉ địinh của nhãn } \\
\text { khoa. Có thề điều trị bằng } \\
\text { lazer khi có bệnh võng mạc } \\
\text { tăng sinh, phù võng mạc } \\
\text { hoặc bệnh võng mạc không } \\
\text { tăng sinh mức độ nặng. }\end{array}$ \\
\hline Bệnh thận & $\begin{array}{l}\text { Thường xuất hiện } \\
\text { tại thời điểm chẩn } \\
\text { đoán; } 14-22 \% \mathrm{khi} \\
\text { khảo sát cắt ngang }\end{array}$ & $\begin{array}{l}\text { Albumin niệu vết } \\
\text { khi 30-299mg/g } \\
\text { - 20-199mcg/ phút } \\
\text { Có thể tăng khi hút } \\
\text { thuốc lá, gắng sức, } \\
\text { hành kinh. Phải loại trừ } \\
\text { protein niệu tư thế và } \\
\text { bệnh thận }\end{array}$ & $\begin{array}{l}\text { Nếu albumin niệu bền bỉ ( } \\
2 \text { lần) bắt đầu sử dụng ức } \\
\text { chế men chuyển thâm chí } \\
\text { huyết áp bình thường. Mục } \\
\text { tiêu đưa MAU về bình } \\
\text { thường. Điều trị tăng huyết } \\
\text { áp }\end{array}$ \\
\hline Trầm cảm & $\begin{array}{l}\text { Găp 14,7\% ở nữ } \\
\text { nhiều hơn nam. }\end{array}$ & $\begin{array}{l}\text { Sàng lọc tại thời điểm } \\
\text { chẩn đoán và định kỳ, } \\
\text { đặc biệt ở đối tượng } \\
\text { kiềm soát glucose máu } \\
\text { kèm và/hoặc thăm } \\
\text { khám thường xuyên khi } \\
\text { nhập vào khoa cấp cứu }\end{array}$ & $\begin{array}{l}\text { Do bác sĩ chuyên khoa tâm } \\
\text { thần điều trị. }\end{array}$ \\
\hline
\end{tabular}

\section{KẾT LUẬN}

Đái tháo đường typ 2 ở trẻ em và vị thành niên là một vấn đề y khoa rất nghiêm trọng vì số lượng ngày càng gia tăng thậm chí còn cao hơn so với ĐTĐT2 ở người lớn, ngày càng trở thành thách thức trong chẩn đoán và hạn chế về các quan điểm điều trị. Lý do trền liên quan đến tỷ lệ cao của biến chứng ĐTĐ và béo phì.

Cách tiếp cận từ phía gia đình là rất quan trọng kết hợp với y học, thay đổi lối sống và khía cạnh tâm thần cần được áp dụng trong chăm sóc, điều trị chung, cần tăng cường giáo dục về ĐTĐ, dinh dưỡng, tâm thần và tham gia của xã hội như là một biện pháp phối hợp chăm sóc bệnh nhân.

\section{TÀI LIỆU THAM KHẢO}

1. Kung-Ting Kao, Matthew A Sabin (2016), "Type 2 diabetes mellitus in children and adolescents". Volume 45, No.6, Pages 401-406.

2. OR Temneanu,LM Trandafir,MR Purcarea(2016). "Type 2 diabetes mellitus in children and adolescents: a relatively new clinical problem within pediatric practice”. J Med Life ; 9(3): 235-239.

3. Cara V. Tillotson, Sameh W. Boktor (2019). "Pediatric Type 2 diabetes mellitus" NCBI Bookshelf.

4. Mayo clinic "Type 2 diabetes in children".

5. Thomas Reinehr (2013)."Type 2 diabetes mellitus in children and adolescents". World J Diabetes, Dec 15; 4(6): 270-281. 